\title{
Prevalence of Tuta absoluta (Meyrick) and Chemical Management in Loitoktok, Kajiado County, Kenya
}

\author{
Ndalo Victor Ruth Gathu Maina Mwangi. \\ School of Agriculture and Enterprise Development, Kenyatta University, \\ P.O.BOX 43844-00100 Nairobi, Kenya
}

\begin{abstract}
The tomato borer, Tuta absoluta, (Meyrick) has invaded the Mediterranean basin recently from South America and it is becoming a major global pest of tomato. Tomato plants can be infested from seedlings to mature plants. In Loitokitok, the pest has devastated tomato grain in the district with yield loss being reported of up to $100 \%$. This has resulted in loss of income for the tomato growers. Chemical control of the pest has been difficult because the pests live inside the leaves, fruits and stems. Excessive use of pesticide is dangerous can develop resistance due to its high reproduction capacity and short generation. This field study was conducted within Loitokitok in Kajiado County to find out the management practices that tomato farmers are currently using to control Tuta absoluta. The aim was to develop the efficacy of a range of insecticides applied against Tuta absoluta and to assess damage levels caused on tomato. A baseline survey was conducted by use questionnaires to collect data from farmers on the damage level, management measures and their efficacy. The results showed that in Loitokitok, tomato growing can be done up to 3 times/year due to good climatic conditions, which provide the pest with abundant all year round and favours its spread. The insecticides that are commonly used are Coragen* (chlorantraniliprole) Belt* (Flubendiamide), Profecron* (profenofos), Radiant* (spinetorum), Escort* (Emamectin Benzoate), and Pentagon*(Lambda-cyhalothrin). Most farmers were using Coragen due to its specific mode of action on several pests on Lepidoptera group. It has good efficacy against T. absoluta larvae. About $46.37 \%$ of the respondents agreed that chlorantraniliprole insecticide used by farmers were effective on the control of pests and farmers were using different insecticides depending on their accessibility and cost. Most farmers recorded the losses of up to $100 \%$ tomato yield due to pest attack.
\end{abstract}

Keywords: Tuta absoluta, Tomato, Chlorantraniliprole, Loitokitok, Kajiado County, Kenya.

DOI: $10.7176 / \mathrm{JBAH} / 9-22-05$

Publication date: November $30^{\text {th }} 2019$

\subsection{Introduction}

The tomato (Solanum lycopersicum) belongs to the Solanaceae family and it is one of the most valued vegetable crops.it originated from South America from where it spread to Europe and later on to East Africa in the $19^{\text {th }}$ century (Wamache, 2005). Over the years, there are several varieties that have been developed for commercial purposes, fresh market and processing (Prasad and Kumar, 2010). The crop is also important as a source of vitamin $\mathrm{C}$, calcium, phosphorus and calories. It also plays a critical role in meeting domestic food requirements, job creation, income and foreign exchange earner. In Kenya tomato production falls under the horticultural crops which are mainly grown under the rainfed conditions and irrigation. Owing to the unpredictable rainfall patterns, people are starting to grow tomato in the greenhouses.

The production areas of tomato in Kenya are Kirinyaga (14\%), Kajiado (9\%) and Taita Taveta (7\%). Tomato production in Kenya is faced by constraints including damage and yield loses due to insect pests attack which has been reported in the East African region. The major important pests of tomato are whitefly (Bemisia tabaci), African bollworm (Helicoverpa armigera), thrips (Ceratothripoides brunneus Bagnall), and red spider mite (Tetranychus spp). Other constraints are lack of improved seeds, drought, diseases, markets and poor soil nutrients (Larsen, 2009).

Tomato leaf miner moth, Tuta absoluta (Meyrick) (Lepidoptera: Gelechiidae) is a new pest Kenya that affects tomato production in both open field and greenhouses. Its reproductive potential is very high with a lifecycle of ranging from 24 to 28 days (Desneux et al., 2010). The most destructive stage of the pest is larvae as it mines the stems, leaves and fruits producing large galleries as they feed on the mesophyll tissue. The common control method used by farmers is chemical control but this is dangerous in that it gets rid of the natural enemies, contaminate the environment and can cause pest resistance in pest populations (Cifuentes et al., 2011). Pesticide resistant to the pest has been reported in pesticides that include Diflubenzuron, Bifethrin, Permethrin, Triflumuron and Teflubenzuron (Silva et al., 2011). This situation is likely to develop in Kenya since the pest is present in Kenya and Kenyans are relying on synthetic pesticide to manage it. The objective of this study was to determine the chemical management practices used by farmers within Loitokitok, Kajiado, County, Kenya.

\subsection{Spread pathways of Tuta absoluta}

Climatic conditions play a critical role in the spread of $T$. absoluta. During the cold season, they maintain their 
viability in the greenhouse and spread to open fields during the hot season (Potting et al., 2009). With favorable, diapause may not occur and its generation may continue the whole year. The pest has an active capacity of dispersal with the adult capable of flying a few kilometers through open fields (Van Deventer, 2009). The pest can spread through agricultural trade between community, countries and border crossings (Cáceres, 1992; Tonnang et al., 2015). The pest population may as well develop as a result of the transportation of infested fruits from production and packing sites and shipping vehicles.

\subsection{Damages caused by Tuta absoluta}

The larva causes damage to all the phenological stages of the plant. The pest damages the seedling and even the mature plants, reducing its yield and fruit quality (Harbi et al., 2012; Oberhuber, 2012). Their feeding method within the mesophyll of the leaves affects the photosynthetic capacity of the crop (Desneux et al., 2010). On the fruit, T. absoluta usually penetrates in an immature state at the ends of the stalk, leaving behind galleries that cause deformation and can create routes for pathogen attack hence enhancing decay of tomato. The secondary rot caused by the pest to the fruit can render it unfit for human consumption (Korycinska and Moran, 2009). Tuta absoluta larvae can penetrate and mine the soft shoots by entering through the apical between the petioles and the leaves (Plate 1). Tomatoes can be damaged at any growth stage, with the females preferring to oviposit on the leaves $(73 \%)$, margins of stem $(21 \%)$, tomato sepal $(5 \%)$ or premature fruit $(1 \%)$ (Estay, 2000$)$.

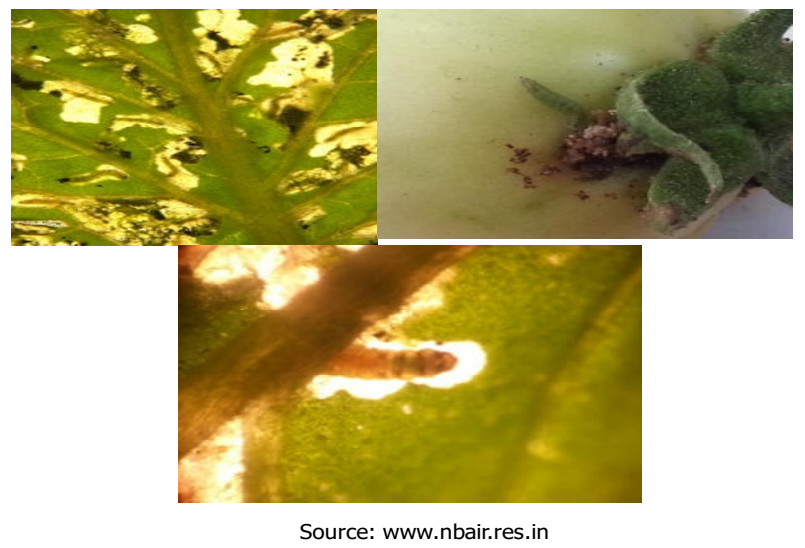

Plate 1: Damages caused by Tuta absoluta to tomato

\subsection{Pest management}

Tuta absoluta is a severe threat to production of tomatoes. The control of the pest generally relies on insecticide application with Diamides being one of the novel insecticides that are highly active against lepidopteran pests (Roditakis et al., 2013). Bacillus thuringiensis var. Kurstaki (Berliner) (Bt) has been proposed to be one of the effective biological control agents for the pest (Moussa et al., 2013). Integrated pest management strategies have been developed to help in controlling the pest, but the widespread use of insecticides has resulted in pest resistance and negative effects to the desirable beneficial arthropods

\subsection{Cultural practices for Tuta absoluta control}

Practicing crop rotation with non-solanaceous crops, adequate irrigation, ploughing, fertilization and removal of infested plant materials are some of the good agricultural practices that should be practiced by farmers (Illakwahhi et al., 2017). Removal of the wild solanaceous host plants should be done as they act as host to all the pest stages which can affect the crop in the following season (Illakwahhi et al., 2017). Using plants free of the pests can help in controlling the pest. In order to prevent population build up, it is important not to leave the infested plant part on the ground so as to prevent the larvae from colonizing the plants (Illakwahhi et al., 2017).

Once the harvesting is done, it is important to destroy the plant residues as soon as possible (Guedes and Picanco, 2012). In warm climates. Soil solarisation may be useful to kill the pupae that may remain in the soil. Screening of greenhouse also helps in preventing entry or exit of the pest. Other practices which can be employed include deep ploughing, rotation with non-solanaceous crops, irrigation and use of resistant varieties (Potting et al., 2009).

2.4 Chemical control of Tuta absoluta

The primary control method of T. absoluta in most countries has been by the use of chemical pesticides. 
Organophosphates have been used but they have been gradually replaced by pyrethroids (Lietti et al., 2005). In the early $1980 \mathrm{~s}$, cartap which was alternated with pyrethroids and thiocyclam was highly efficient in the control of the pest (Siqueira et al., 2000). In the 1990s, novel insecticides such as spinosad, abamectin, tebufonozide and chlorofenapyr were used in controlling the pest (dos Santos et al., 2011; Gontijo et al., 2013). Literature shows that the pest developed resistance to abamectin, cartap, methamidophos and permethrin in Brazil and Argentina (Lietti et al., 2005). Use of chemicals has disrupted IPM programs based on the use of biological agents to control pest population (Potting et al., 2009). Application of contact pesticides has been a challenge due to the feeding method of the pest within the mines; this makes it difficult to reach the target pest (Lietti et al., 2005).

\subsection{Use of pheromone traps to manage the pest}

The pheromone traps are majorly based on adult captures which are important in reducing T. absoluta population (Faccioli, 1993; Benvenga et al., 2007). According to Benvenga et al. (2007), pheromone traps in Brazil are effective in reducing the pest population. Mass trapping has been one of the effective methods in removing males to lower the overall T. absoluta population levels (Witzgall et al., 2008, 2010). Mating disruption has been used in the past to control population build-up of T. absoluta whereby it creates sexual confusion in males by saturating the atmosphere using a synthetic female pheromone in order to prevent mating consequently reducing their population (Cocco et al., 2013).

\subsection{Biological control of Tuta absoluta}

2.6.1 Parasitoids associated with Tuta absoluta

Use of both egg and larval parasitoid of T. absoluta has been reported in the Mediterranean basin (Polaszek, 2009; Desneux et al., 2010). Egg parasitoid, Trichogramma achaeae (Achacolor) (Hymenoptera: Trichogrammatidae) has been reported to reduce the pest population by over 90\% (Cabello et al., 2009; Polaszek et al., 2011). Inundative release of T. exiguum as part of broad IPM strategy has been successful in Colombia, with parasitism rates of over 20\% in open tomato fields (Salas, 2001; Cabello et al., 2009). Biological control by use of Trichogramma species has been documented in Argentina, Colombia, Brazil and Chile (Ferracini et al., 2012). In Brazil, T. pretiosum parasitism rate of $87 \%$ on T. absoluta has been reported in greenhouses (Ferracini et al., 2012). According to Ferracini et al. (2012) the most abundant and effective biological control agents of T. absoluta are Necremnus artynes (Walker) (Hymenoptera: Eulophidae) and N. tidius (Walker) (Hymenoptera: Eulophidae). These parasitoids showed good adaptation to the invasive as they reduced the pest larval mortality with a greater percentage (Luna et al., 2012; Calvo et al., 2013). Research has shown that the solitary larval parasitoid Agathis fuscipennis (Zetterstedt) (Hymenoptera: Braconidae) can parasitize T. absoluta by up to $20 \%$ of the larval population while Pseudoapanteles dingus (Hymenoptera: Braconidae), a solitary larval parasitoid can achieve up to $30 \%$ (Urbaneja et al., 2012).

Larval parasitoid Stenomesius japonicas (Ashmead) (Hymenoptera: Eulophidae) have been identified in Egypt and it parasitizes the second and third instars larvae of tomato leaf miner (James and Stevens, 1992). More recently, Neochrysocharis formosa (Westwood) (Hymenoptera: Eulophidae) has been reported in Africa to parasitize T. absoluta first instar larvae (Zappala et al., 2013). Bracon nigricans (Szepligeti) (Hymenoptera: Braconidae) a gregarious, idiobiont parasitoid that prefers parasitizing the fourth larval instar has recently been identified (Zappala et al., 2012).

2.6.2 Predators associated with Tuta absoluta

Some of the predators linked with various T. absoluta developmental stages are from the order Acari, Araneae, Coleoptera, Dermaptera, Hemiptera, Neuroptera, Thysanoptera and Hymenoptera (Cocco et al., 2013). They include insidious flower bug Orius insidiosus (Hemiptera: Anthocoridae), Spined soldier bug Podisus nigrispinus (Hemiptera: Pentatomidae), Six-spotted Thrips Scolothrips sexmaculatus (Thysanoptera: Thripidae), and paper wasp Polistes melanosoma (Hymenoptera: Vespidae). According to Oliveira et al. (2009), the mite Pyemotes sp (Acarina: Tarsonemoidea) feeds on the pest larvae, pupae and adults hence it is important to use as a bio-control agent. The predatory stinkbug Podisus nigrispinus (Hemiptera: Pentatomidae) has had scientific attention in its use as a biocontrol agent (Cocco et al., 2013).

The green lacewing, Chrysoperla externa (Neuroptera: Chrysopidae) is an important predator of the pest larvae under laboratory conditions. Among the reported predators, Xylocoris sp., and C. sanguinea are key predators of both the egg and larval predators (Miranda et al., 2005). Orius insidiosus has been shown to be a very effective predator of T. absoluta eggs and larvae. According to Ghoneim (2014), Nabis spp. (Heteroptera: Nabidae), spiders and Polistes spp. (Hymenoptera: Vespidae), are some of the key predators in the Chilean tomato farms. Protonectarina sylveirae (Saussure) can cause up to 37.4\% larval mortality (Bacci et al., 2008). Some of the important pupa predators that are effective against $T$. absoluta are Labidura riparia (Dermaptera: Labiduridae) (Pallas), Solenopsis geminata, Pheidole sp. (Hymenoptera: Formicidae), wolf spiders (Araneae: Lycosidae) and ground beetles (Miranda et al., 2005). 


\subsection{Management of Tuta absoluta using microbials}

Bacillus thuringiensis var. kurstaki is one of the entomopathogenic bacteria that have been found to act against $T$. absoluta. It has the capability of causing death on all the larval instars of the pest (Giustolin et al., 2001). Other important entomopathogens belong to the families of Heterorhabditidae and Steinernematidae, which are obligate parasites. They kill the pest through mutual association with bacteria that inhabits the intestines of the ineffective juvenile (Boemare, 2002). According to Urbeneja et al. (2012), the vulnerability of these nematodes to various insecticides has also been tested to assess their capability of integration in the control of the invasive pest.

As a result, an IPM strategy that is environmentally safe and cost-effective need to be developed to help in the management of the pest (Benvenga et al., 2007). Currently little research has been done in Kenya on the population growth of $T$. absoluta and the impact that it has on tomato. Identification of the most effective indigenous natural enemy that is able to adapt to the new host as an alternative control has also not been documented (IPPC, 2014).

\subsection{Research Methodology}

\subsection{Survey of Tuta absoluta in Loitokitok}

The survey was conducted in Loitokitok district which is categorized among the semi-arid districts in Kenya. Loitokitok was chosen for the survey as it is well known for the production of tomatoes for commercial purpose in the country. The main reason for conducting the survey was to evaluate the various important pests of tomato and the current management practices employed by farmers in controlling $T$. absoluta. The farm families are estimated to be 30,000 , out of which 1,550 are tomato growers. Using the information obtained from the local Ministry of Agriculture, survey sites were purposively selected based on the major tomato production areas which included Kisangani, Empironi, and Namelok.

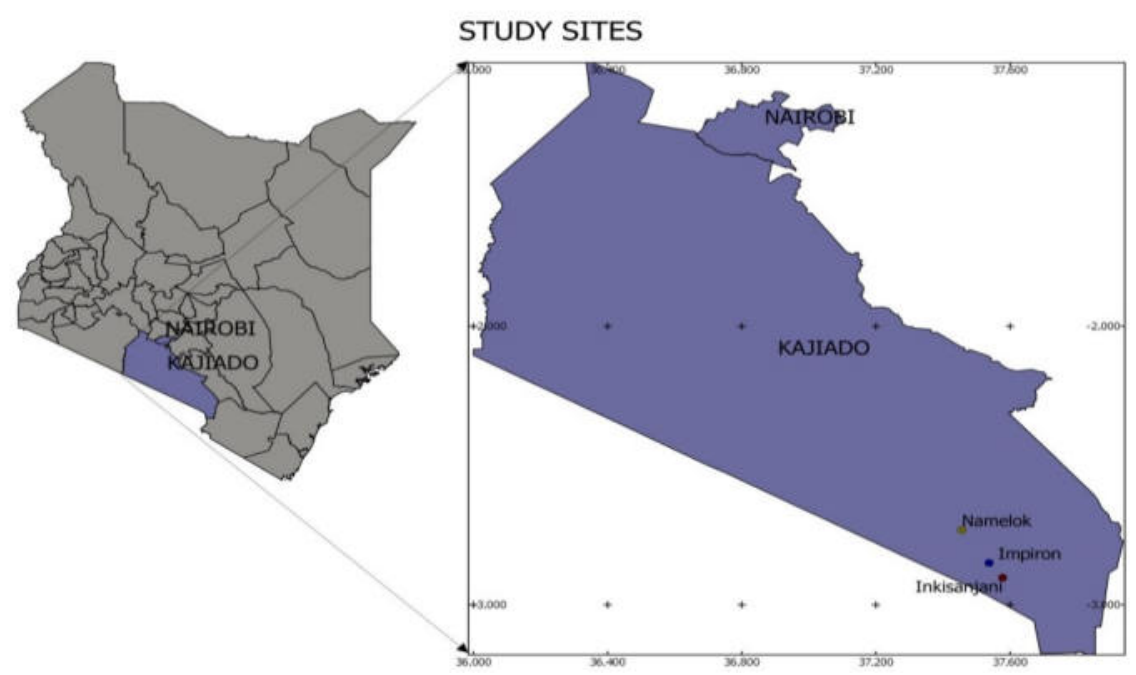

Figure 2: Geographical Location of the study area in Loitokitok

\subsection{Sampling procedure}

According to the 2009 census in Kenya, the study area had a population of 137,496 persons in total. A structured questionnaire was administered to 76 tomato farmers who were randomly selected. According to Mugenda and Mugenda (1999), randomly selecting respondents allows every member with equal opportunity to be chosen so as to have a representative sample.

In this study, Cochran (1963) formula was employed in coming up with the sample size of respondents

Where:

$$
n=\mathrm{pqz}^{2} / \mathrm{e}^{2}
$$

$n=$ Sample size

$z=$ level of confidence interval at $95 \%$ hence $z=1.96$

$p=$ Proportion in the target population estimated to have characteristics being measured;

$e=$ desired level of precision $(5 \%)$.

$$
q=1-p
$$

In this study, $p$ is described as farm families' proportion in Loitokitok district who are growing tomatoes, which is 1,550 out of 30,000 farm families in Loitokitok.

$$
n=1.96^{2} * 0.052 * 0.95 /(0.05)^{2}=76
$$




\subsection{Sampling and data collection}

Both primary and secondary data were collected in this study. Primary data were obtained by the use of a structured questionnaire, which was administered to tomato growers. Sample size was calculated to be 75.89 and rounded off to 76. However, 90 tomato growers were interviewed to ensure that the number of valid questionnaires was not significantly affected by cases of unreliable data or lack of response from the respondents. Secondary data were obtained from the ministry of agriculture records and literature review. A close-ended questionnaire was administered to farmers by a face-to-face interview in their farms. Data were collected on farmer's gender, age, education, preferred tomato variety, farmer's knowledge on important tomato insect pests, land allocated for the production of tomatoes, and the current management practices for T. absoluta.

\subsection{Data analysis}

Data from the survey was analyzed using descriptive statistics based on percentage of occurrences reported by the respondents. The Statistical Package for Social Sciences (SPSS) version 20.0 was used in analyzing the data on the survey.

\subsection{Results and discussion}

\subsection{The socio-demographic characteristics of tomato farmers}

In Loitokitok, men constituted the majority of the respondents who were sampled within Empironi (71.4\%), Namelock (73.1\%) and Kisangani (69.0\%). The age profiles of those who were sampled in both locations was spread across the age group. However, the young population were generally high the sample with about $47.6 \%$ of the respondents being under the age of 40 years. In both locations, most of the tomato growers had completed primary level of education with less than $3.9 \%$ having completed tertiary education. Those who managed to complete their secondary education ranged between $19 \%$ and $44.8 \%$ (Table 1 ).

Table 4: Table showing the demographics of sampled tomato growers' respondents

\begin{tabular}{llccc}
\hline Survey locations & & Empironi (\%) & Namelock (\%) & Kisangani (\%) \\
\hline Gender & Male & 71.4 & 73.1 & 69.0 \\
& Female & 28.6 & 26.9 & 31.0 \\
\hline Age & Below 20 & 4.7 & 7.8 & 3.4 \\
& $21-30$ & 23.9 & 34.6 & 31.0 \\
& $31-40$ & 47.6 & 30.8 & 42.3 \\
& $41-50$ & 23.8 & 15.4 & 17.2 \\
& Above 50 & 0.0 & 11.5 & 10.3 \\
\hline \multirow{2}{*}{ Level of education } & Primary & 81 & 61.5 & 51.7 \\
& Secondary & 19 & 34.6 & 44.8 \\
& Tertiary & 0 & 3.9 & 3.4 \\
\hline
\end{tabular}

\subsection{Farmers' knowledge on important tomato pests}

Results from the survey showed that, currently, T. absoluta $(52.3 \%)$ is the most devastating pest faced by tomato farmers within the district. Apart from T. absoluta, other pests are whitefly, mites, thrips, aphids and leaf miner (Figure 2). During the survey, most tomato farms were $80 \%$ damaged by the invasive pest and farmers had to sort out tomato fruits for commercial purpose from the destroyed farms. The rest of the tomato fruits were left for the livestock to feed on. 


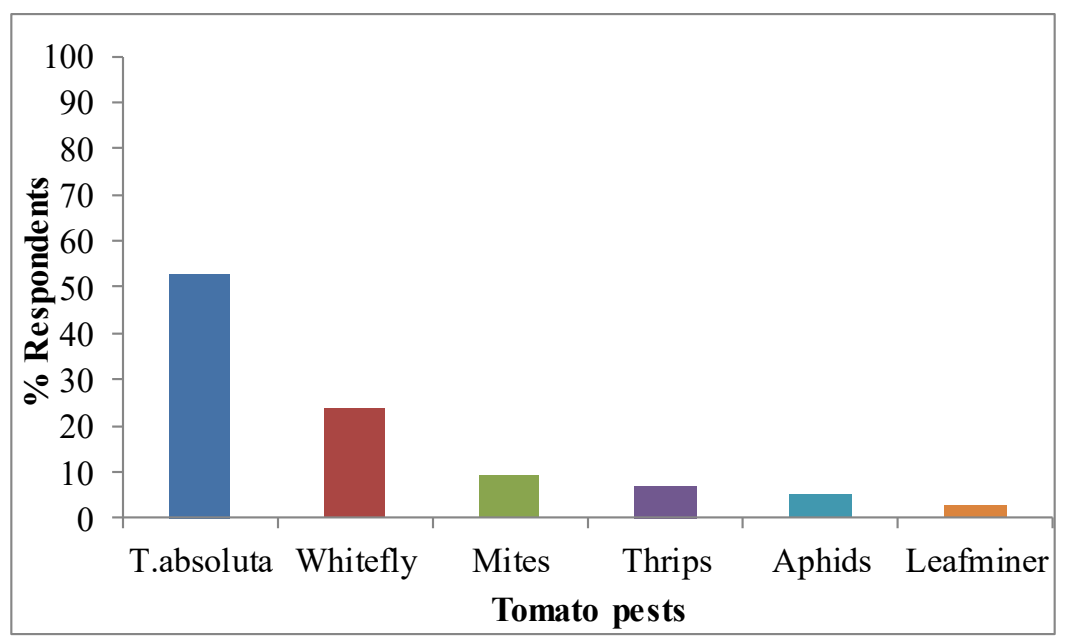

Figure 3: Figure showing important tomato pests within Loitokitok

4.3 Selected types of cultivated and consumed tomato varieties within Loitokitok-Kajiado County

Results from the survey showed that there was a diversity of tomatoes being cultivated and consumed within the county. These included Tylka F1, Kilele, Rio grande, Onex, Elgon, Danish, and Mkulima. The survey revealed preference for Rio grande (48.7\%) variety among the tomato growers. The rest of the varieties were less preferred by the sampled respondents (Figure 3 ).

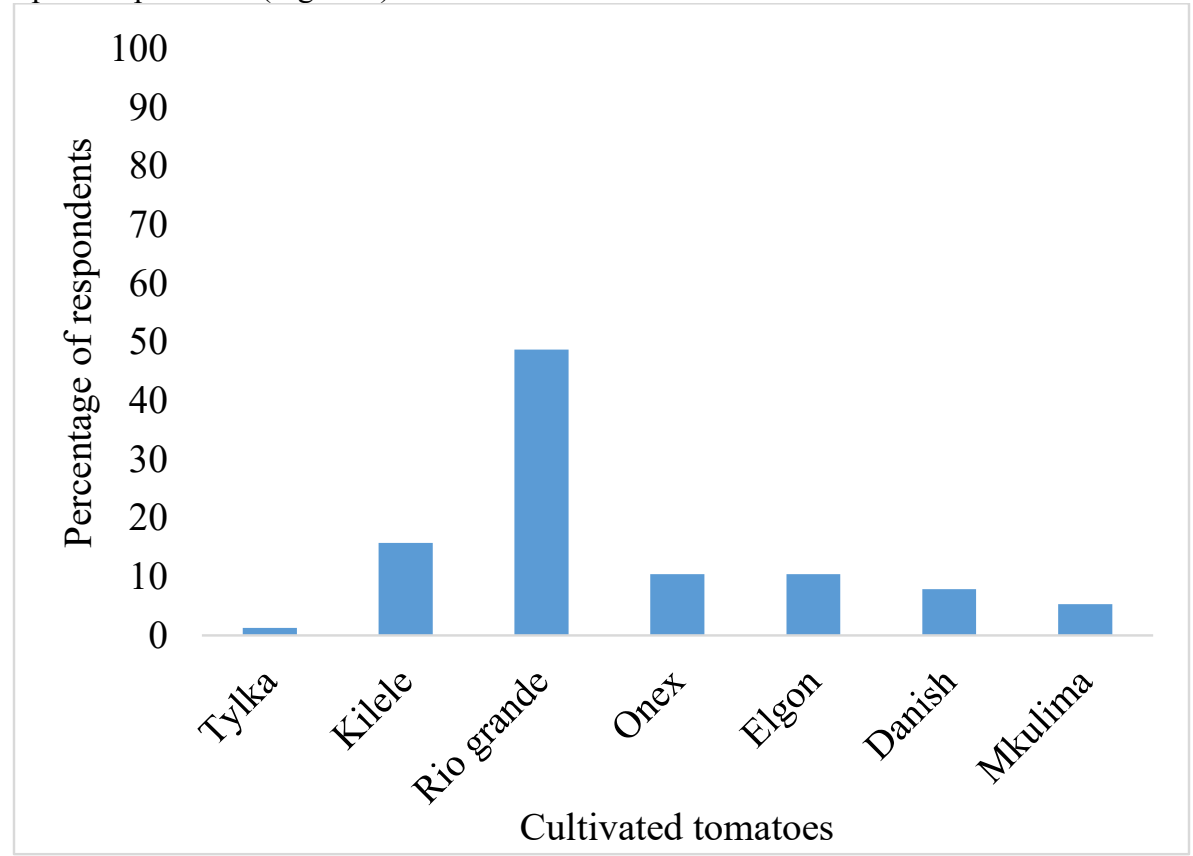

Figure 4: Most preferred tomato variety within Loitokitok as per the respondents

4.4 Constraints facing tomato production in Loitokitok and sources of seeds

The major constraints facing tomato production were water shortage, pests and diseases, poor seed quality and lack of technical assistance. Pests and diseases were the main constraints to production of tomatoes followed by shortage of water and lack of technical advice. Majority of tomato growers relied on certified seeds obtained from the Agricultural and Veterinary shops (agrovets) while minority used own home saved seeds from the previous season. There were also those who were using both the saved and agrovets seeds (Table 2). 
Table 5: Challenges facing tomato production and sources of seeds for tomato growers

\begin{tabular}{lc}
\hline Constraints & Percentage of respondents $(\mathbf{N}=\mathbf{7 6})$ \\
\hline Pests and diseases & 50.0 \\
Water shortage & 19.7 \\
Lack of technical advice & 17.1 \\
Poor seed quality & 6.6 \\
Others & 6.6 \\
\hline Sources of seeds & \\
\hline Home saved & 26.3 \\
Agrovets & 67.1 \\
Home saved + Agrovets & 6.6 \\
\hline
\end{tabular}

\subsection{Current management practices of $T$. absoluta}

There are two management practices that are being employed by farmers to control T. absoluta, chemical control and agronomic practices. The management practice widely used is chemical control. Currently, various chemicals are used by farmers within the district for the control of T. absoluta as shown in (Table 3). Results showed that Chlorantraniliprole $(46.4 \%)$ is the most widely used followed by Flubendiamide $(32.3 \%)$. However, farmers are not limited to the use of only Chlorantraniliprole and Flubendiamide. Other pesticides used are Profenofos (8.5\%), Lambda-cyhalothrin (1.4\%), Abamectine (4.1\%), Emamectin Benzoate (3.4\%), and Spinetoram (3.4\%) (Table 3). Table 6: Types and proportion of pesticides used by farmers to manage Tuta absoluta within Loitokitok district

\begin{tabular}{lll}
\hline Active ingredient & Formulation & Percent \% (N=76) \\
\hline Chlorantraniliprole & SC & 46.4 \\
Flubendiamide & SC & 32.3 \\
Profenofos & EC & 8.5 \\
Lambda-cyhalothrin & WP & 1.4 \\
Abamectine & SC & 4.6 \\
Emamectin Benzoate & SG & 3.4 \\
Spinetoram & SC & 3.4 \\
\hline
\end{tabular}

SC- Suspension Concentrate; EC - Emulsifiable concentrate; WP - Wettable Powder; Soluble granule

\subsection{Discussion}

The gender results can be explained by the fact that Loitokitok is far from the major city in Kenya where the demand for tomato is more than $90 \%$ of supply coming from farms that are within its environs (Otieno et al., 2009). This implies therefore that men may have discovered the opportunity of high income from cultivation of tomato and as a remedy of unemployment. According to Schippers and Fereday (2010), once an enterprise picks up, males tend to participate more than the females.

In terms of age profiles, it is one of the important factors affecting the effectiveness of carrying out farm activities from which more effort is needed in order to realize maximum benefits. Age is also associated with the experience that the farmer has gained over time specifically in regards to tomato production. It is in this regard that many youths who are above 30 years were engaging in tomato production as they are also able to access credit facility unlike those who were below 20 years. This is in agreement with Mwaura et al., (2014) who reported that access to credit facility is important to the success of farming.

Social-cultural factors can be the main reasons for low formal education affecting most tomato growers in Loitokitok. Longer distances to schools, early marriage, lack of interest by parents, and forced marriage are some of the constraints in access to education (Amwata et al., 2016). Education is an important factor in tomato production in that it allows the farmers to have knowledge on several aspects of production including marketing strategies, pesticide application, investments, and environmental tolerance before embarking on production.

According to Chepng and Boit (2015), farmers with secondary school level agricultural knowledge perform significantly better in farming when compared to those without. Amao and Awoyemi (2008) also noted that the more educated a farmer is, the more likely they are to have high income.

This study found that there are various tomato insect pests that farmers are aware of through the help of agricultural extension officers within the district and research institutions such as ICIPE. According to farmers, the current most severe threat to tomato production is the invasive pest $T$. absoluta. The high damage level by the invasive pest could be due to several attributes of the pest that makes it difficult to control. Some of the attributes documented by Cabello et al. (2009) are short generation time, flexible pupation site, and larval mining behaviour. Moreover, the high damage level might be as a result of farmers' lack of knowledge on control strategies, as $T$. absoluta is a relatively new pest in the area. 
The survey revealed that Rio grande was the most preferred tomato variety. This owes to the fact that the variety take shorter time to bloom, days to set fruits and maturity. Due to its high fruit formation, farmers preferred it for commercial purposes. This is in agreement with the study conducted by Hussain et al. (2001) who reported that Rio grande tomato variety has high yield potential for summer production.

Since its arrival in Kenya, T. absoluta has spread rapidly thus increasing the cost of management options for tomato production. Currently, farmers are depending majorly on chemical control to help in its reduction. According to Lietti et al. (2005), chemical use is the main control method against T. absoluta in newly invaded regions. Chlorantraniliprole is currently the most widely used insecticide with majority of the farmers confirming its effectiveness in reducing the pest population. Roditakis et al. (2013a; 2013b) reported high resistance development of $T$. absoluta against chlorantraniliprole compared to other chemicals. The results are also in agreement with the study that was done by Ayalew (2015) who found that different pesticides act differently in the control of $T$. absoluta. Ayalew, (2015) reported that the population of the pest was lower when Diamide ${ }^{\circledR}$ (flubendiamide) and Spinosyns (spinosad) were used than when other pesticides were used to control T. absoluta. Mahmoud et al. (2014) reported that Chlorantraniliprole is the most effective chemical in the control of T. absoluta. This result is also in agreement with Roditakis et al. (2013) who conducted research on the efficacy of various chemicals against $T$. absoluta and found that Chlorantraniliprole is the most effective pesticide.

The survey showed that $T$. absoluta was the most serious pest affecting tomato growers within the region. This could have been due to the fact that the pest has unique feeding behaviours and high fecundity within a short period of time. In addition, since its introduction to the country in 2014, there have been no effective strategies of control available to the farmers. There was also low awareness among the farmers on the pest threat levels and control. These assertions are in agreement with Illakwahhi et al. (2017) who reported that lack of sound strategies to control the pest can increase the spread of the pest to new areas.

Some of the common agronomic practices by farmers to control the pest include clearing of the farm, followed by ploughing, which helps in exposing the pest to predators and the sun or suffocates it under the soil (Oztemiz, 2014). During cropping season, it was noted that the farmers are irrigating their farms once every week and this is important as it helps in reducing the larval and pupal population that might have fallen onto the ground to pupate. Another important agronomic practice that was noted is crop rotation which is widely practiced in the area. Farmers within the area alternate tomato with other crops such as beans, capsicum, maize and vegetables. Though it is to be recommended, crop rotation should be practiced with caution as it can contribute to high pest population throughout the year. This happens when tomato is alternated with other alternative host such as eggplant. Michereff et al. (2000) reported that alternating tomatoes with other Solanaciuos crops which act as an alternative host to the pest can help in sustaining its population.

\section{Conclusion}

The survey study showed that Chlorantraniliprole was being used by most farmers to control the larvae of $T$. absoluta. Chlorantraniliprole is the main chemical insecticide used by farmers. The chemical can be alternated with other chemical products and integrated pest management to help in controlling the pest.

\section{References}

Amao, J. O. and Awoyemi, T. T. (2008). Adoption of improved cassava varieties and its welfare effect on producing households in Osogbo ADP zone of Osun state. Retrieved on 25 June 2012 from www.geneconserve.pro.br/artigo045.pdf

Amwata, D. A., Nyariki, D. M. and Musimba, N. R. (2016). Factors influencing pastoral and agropastoral household vulnerability to food insecurity in the drylands of Kenya: a case study of Kajiado and Makueni Counties. Journal of International Development, 28(5), 771-787.

Bacci, L., Picando, M. C., Sousa, F. F., Silva, E. M., Campos, M. R. and Tomé, H.V.T (2008). Natural enemies of tomato tract. Brazilian Horticulture, 26, 2808-2812.

Benvenga, S. R., Fernandes, O. A. and Gravena, S. (2007). Decision making for integrated pest management of the South American tomato pinworm based on sexual pheromone traps. Brazilian Horticulture, 25,164-169.

Boemare, N. O. E. L. (2002). Systematics of Photorhabdus and Xenorhabdus. Entomopathogenic nematology. CABI Publishing, New York, 35-56.

Cabello, T., Gallego, J. R., Vila, E., Soler, A., Del Pino, M., Carnero, A. and Polaszek, A. (2009). Biological control of the South American tomato pinworm, Tuta absoluta (Lep.: Gelechiidae), with releases of Trichogramma achaeae (Hym.: Trichogrammatidae) in tomato greenhouses of Spain. International Organization for Biological and Integrated Control, 49, 225-230.

Cáceres, S. (1992). The tomato moth in Corrientes: biology and control. INTA. Bella Vista, Corrientes (Argentina), p19.

Calvo, F. J., Soriano, J. D., Bolckmans, K. and Belda, J. E. (2013). Host instar suitability and life-history parameters under different temperature regimes of Necremnus artynes on Tuta absoluta. Biocontrol Science 
and Technology, 23(7), 803-815.

Chepng, E. and Boit, R. (2015). Contribution of secondary school agricultural knowledge on farmers 'crop and livestock diversification activities in Uasin-Gishu County, Kenya. International Journal of Innovative Agriculture \& Biology Research, 3(3), 18-26,

Cifuentes, D., Chynoweth, R. and Bielza P. (2011). Genetic study of Mediterranean and South American populations of tomato leaf miner Tuta absoluta (Povoiny, 1994) (Lepidoptera: Gelechiidae) using ribosomal and mitochondrial markers. Pest Management. Sci. wileyonelibrary.com.

Cocco, A., Deliperi, S. and Delrio, G. (2013). Control of Tuta absoluta (Meyrick) (Lepidoptera: Gelechiidae) in greenhouse tomato crops using the mating disruption technique. Journal of Applied Entomology, 137(1-2), 16-28.

Cocco, A., Deliperi, S. and Delrio, G. (2013). Control of Tuta absoluta (Meyrick) (Lepidoptera: Gelechiidae) in greenhouse tomato crops using the mating disruption technique. Journal of Applied Entomology, 137(1-2), 16-28.

Cochran, W. G. (1963). Sampling Techniques, 2nd Ed., New York: John Wiley and Sons, Inc.

Desneux, N., Luna, M. G., Guillemaud, T. and Urbaneja, A. (2011). The invasive South American tomato pinworm, Tuta absoluta, continues to spread in Afro-Eurasia and beyond: the new threat to tomato world production. Journal of Pest Science, 84(4), 403-408.

Desneux, N., Wajnberg, E., Wyckhuys, K. A., Burgio, G., Arpaia, S., Narváez-Vasquez, C. A. and Pizzol, J. (2010). Biological invasion of European tomato crops by Tuta absoluta: ecology, geographic expansion and prospects for biological control. Journal of pest science, 83(3), 197-215.

dos Santos, A. C., Bueno, R. D. F., Vieira, S. S. and Bueno, A. D. F. (2011). Efficacy of insecticides on Tuta absoluta (Meyrick) and other pests in pole tomato. Embrapa Soja-Article in indexed journals (ALICE), 6 (6), $1-6$.

Estay, P. (2000). Tomato Moth Tuta absoluta (Meyrick). URL http://alerce.inia.cl/docs/Informativos/ Informativo09.pdf.

Ferracini, C., Ingegno, B. L., Navone, P., Ferrari, E., Mosti, M., Tavella, L. and Alma, A. (2012). Adaptation of indigenous larval parasitoids to Tuta absoluta (Lepidoptera: Gelechiidae) in Italy. Journal of Economic Entomology, 105(4), 1311-1319.

Ferracini, C., Ingegno, B. L., Navone, P., Ferrari, E., Mosti, M., Tavella, L. and Alma, A. (2012). Adaptation of indigenous larval parasitoids to Tuta absoluta (Lepidoptera: Gelechiidae) in Italy. Journal of Economic Entomology, 105(4), 1311-1319.

Ghoneim, K. (2014). Predatory insects and arachnids as potential biological control agents against the invasive tomato leafminer, Tuta absoluta Meyrick (Lepidoptera: Gelechiidae), in perspective and prospective. Journal of Entomology and Zoology Studies, 2(2), 52-71.

Giustolin, T. A., Vendramim, J. D., Alves, S. B., Vieira, S. A. and Pereira, R. M. (2001). Susceptibility of Tuta absoluta (Meyrick) (Lep., Gelechiidae) reared on two species of Lycopersicon to Bacillus thuringiensis var. kurstaki. Journal of Applied Entomology, 125(9 - 10), 551-556.

Gontijo, P. C., Picanço, M. C., Pereira, E. J. G., Martins, J. C., Chediak, M. and Guedes, R. N. C. (2013). Spatial and temporal variation in the control failure likelihood of the tomato leaf miner, Tuta absoluta. Annals of applied biology, 162(1), 50-59.

Guedes, R. N. C. and Picanço, M. C. (2012). The tomato borer Tuta absoluta in South America: pest status, management and insecticide resistance. EPPO bulletin, 42(2), 211-216.

Harbi, A., Abbes, K. and Chermiti, B. (2012). Evaluation of two methods for the protection of tomato crops against the tomato leafminer Tuta absoluta (Meyrick) under greenhouses in Tunisia. EPPO bulletin, 42(2), 317-321.

Hussain, S. I., Khokhar, K. M., Mahmood, T., Laghari, M. H., Mahmud, M. M. (2001). Yield potential of some exotic and local tomato cultivars grown for summer production. Pakistan Journal of Biological Sciences, 10(4), 1215-1216.

Illakwahhi, D.T., Bali, B. and Srivastava, L. (2017). Control and Management of Tomato Leafminer -Tuta Absoluta (Meyrick) (Lepidotera, Gelechiidae). IOSR Journal of Applied Chemistry (IOSR-JAC) e-ISSN: 2278-5736, $10 \quad$ (6), 14-22. $\quad$ http://www.iosrjournals.org/iosr-jac/papers/vol10-issue6/Version$1 / \mathrm{C} 1006011422 . \mathrm{pdf}$.

IPPC, (2014). New Pest in Kenya: Preliminary surveillance report on Tuta absoluta. file:///H:/new-pest-kenyapreliminary-surveillance-report-tuta-absoluta.html

James, D. G. and Stevens, M. M. (1992). Stenomesius japonicus (Ashmead) (Hymenoptera: Eulophidae), a parasitoid of the introduced biological control agent Dialectica scalariella (Zeller) (Lepidoptera: Gracillariidae). Australian Journal of Entomology, 31(3), 233-234.

Lietti, M. M., Botto, E. and Alzogaray, R. A. (2005). Insecticide resistance in argentine populations of Tuta absoluta (Meyrick) (Lepidoptera: Gelechiidae). Neotropical Entomology, 34(1), 113-119.

Luna, M. G., Sánchez, N. E. Pereyra, P. C., Nieves, E., Savino, V., Luft, E. and Speranza, S. (2012). Biological 
control of Tuta absoluta in Argentina and Italy: evaluation of indigenous insects as natural enemies. EPPO bulletin, 42(2), 260-267.

Mahmoud, Y.A., Salem, H.A., Shalaby, E.M., Abdel-Razak, A.S. and Ebadah, M.A. (2014). Effect of Certain Low Toxicity Insecticides Against Tomato Leaf Miner, Tuta absoluta (Lepidoptera: Gelechiidae) with Reference to Their Residues in Harvested Tomato Fruits. International Journal of Agricultural Research, 9, 210-218.

Michereff, M., Vilela, E. F., Jham, G. N., Attygalle, A., Svatos, A. and Meinwald, J. (2000). Initial studies of mating disruption of the tomato moth, Tuta absoluta (Lepidoptera: Gelechiidae) using synthetic sex pheromone. Journal of the Brazilian Chemical Society, 11(6), 621-628.

Miranda, M. M. M., Picanço, M. C., Zanuncio, J. C., Bacci, L. and Silva, É. M. D. (2005). Impact of integrated pest management on the population of leafminers, fruit borers, and natural enemies in tomato. Rural Science, 35(1), 204-208.

Moussa, S., Sharma, A., Baiomy, F. and El-Adl, F. E. (2013). The Status of Tomato leafminer, Tuta absoluta (Meyrick) (Lepidoptera: Gelechiidae) in Egypt and potential effective pesticides. Academic Journal of Entomology, 6(3), 110-115.

Mugenda, O.M and Mugenda. A.G. (1999). Research methods quantitative and qualitative approaches. Olive., M. Publication, Nairobi Acts, 1999. p256.

Mwaura, S.N. Muluvi, A.S. and Mathenge, M.K. (2014). African Leafy Vegetables and Household Wellbeing in Kenya: A Disaggregation by Gender. Current Research Journal of Social Sciences, 6(4), 82-94

Oberhuber, M. (2012). The tomato leaf miner- Tuta absoluta: Biology, occurrence and damage caused. http://www.dnw.boku.ac.at/fileadmin/data/H03000/H95000/H95300/Angewandte Entomologie/WS11 12/ Oberhuber.pdf

Oliveira, F. A., da Silva, D. J. H., Leite, G. L. D., Jham, G. N. and Picanço, M. (2009). Resistance of 57 greenhousegrown accessions of Lycopersicon esculentum and three cultivars to Tuta absoluta (Meyrick) (Lepidoptera: Gelechiidae). Scientia Horticulturae, 119(2), 182-187.

Otieno, D.J. Omiti J. Nyanamba, T. and McCullough, E. (2009). Market participation by vegetable farmers in Kenya: A comparison of rural and peri-urban areas. African Journal of Agriculture Research, 4(5),451-60

Oztemiz, S. (2014). Tuta absoluta Povolny (Lepidoptera: Gelechiidae), The Exotic Pest in Turkey. Romanian Journal of Biology, 59(1), 47-58.

Polaszek, A. (2009). Species diversity and host associations of Trichogramma in Eurasia. In Egg Parasitoids in Agroecosystems with Emphasis on Trichogramma, Springer Netherlands, 237-266.

Polaszek, A., Rugman-Jones, P. F., Stouthamer, R., Hernandez-Suarez, E., Cabello, T. and del Pino Pérez, M. (2011). Molecular and morphological diagnoses of five species of Trichogramma: biological control agents of Chrysodeixis chalcites (Lepidoptera: Noctuidae) and Tuta absoluta (Lepidoptera: Gelechiidae) in the Canary Islands. BioControl, 57(1), 21-35.

Potting, R., Van der gaag, D.J. and Loomans A. (2009). Tuta absoluta, Tomato Leaf Miner Moth or South American Tomato Moth. Ministry of Agriculture, Nature and Food Quality (LVN) Plant Protection Service of the Netherlands. Available at: http://www.minlnv.nl.

Potting, R., Van der gaag, D.J. and Loomans A. (2009). Tuta absoluta, Tomato Leaf Miner Moth or South American Tomato Moth. Ministry of Agriculture, Nature and Food Quality (LVN) Plant Protection Service of the Netherlands. Available at: http://www.minlnv.nl.

Prasad, S. and Kumar, U. (2010). Greenhouse management for horticultural crop protection, 57pp Publishing Company, Gaborone, Botswana.

Roditakis, E., Skarmoutsou, C. and Staurakaki, M. (2013). Toxicity of insecticides to populations of tomato borer Tuta absoluta (Meyrick) from Greece. Pest management science, 69(7), 834-840.

Roditakis, E., Skarmoutsou, C., Staurakaki, M., del Rosario Martínez - Aguirre, M., García - Vidal, L., Bielza, P. and Teixeira, L. A. (2013). Determination of baseline susceptibility of European populations of Tuta absoluta (Meyrick) to indoxacarb and chlorantraniliprole using a novel dip bioassay method. Pest management science, 69(2), 217-227.

Salas, J. (2001). Presence of Orius insidiosus (Hemiptera: Anthocoridae) in central-western region on Venezuela. Agronomy Tropical, 45(4), 637-645.

Schippers, R., and Fereday, N. (2010). Opportunities and Constraints in the Subsistence Production and Marketing of Indigenous Vegetables in East and Central Africa. R4D Project.

Silva, G.A., Picanco, M.C., Bacci, L., Crespo, A.L.B., Rosado, J.F. and Guedes, R.N.C. (2011). Failure likelihood and spatial dependence of insecticide resistance in the Tomato pinworm, Tuta absoluta. Pest Management Science, 67: 913-920.

Siqueira, H. A. A., Guedes, R. N. C. and Picanco, M. C. (2000). Cartap resistance and synergism in populations of Tuta absoluta (Lep., Gelechiidae). Journal of Applied Entomology, 124(5 - 6), 233-238.

Tonnang, H. E., Mohamed, S. F., Khamis, F. and Ekesi, S. (2015). Identification and Risk Assessment for Worldwide Invasion and Spread of Tuta absoluta with a Focus on Sub-Saharan Africa: Implications for 
Phytosanitary Measures and Management. PloS one, 10(8), e0135283.

Urbaneja, A., González - Cabrera, J., Arnó, J. and Gabarra, R. (2012). Prospects for the biological control of Tuta absoluta in tomatoes of the Mediterranean basin. Pest management science, 68(9), 1215-1222.

Van Deventer, P. (2009). Leaf miner threatens tomato growing in Europe (Crop protection). Fruit and Vegetable technology, 9(2009), 10-12.

Wamache, K. (2005) Vegetable seeds handbook. Regina seeds seminis.Printed by Bizone ltd Nairobi Kenya 2325.

Witzgall, P., Kirsch, P. and Cork, A. (2010). Sex pheromones and their impact on pest management. Journal of chemical ecology, 36(1), 80-100.

Witzgall, P., Stelinski, L. Gut, L. and Thomson, D. (2008). Codling moth management and chemical ecology. Annual Review of Entomology, 53, 503-522.

Zappala, L., Bernardo, U., Biondi, A., Cocco, A., Deliperi, S., Delrio, G., Giorgini, M., Pedata, P., Rapisarda, C., Garzia, G.T. and Siscaro, G. (2012). Recruitment of native parasitoids by the exotic pest Tuta absoluta (Meyrick) in southern Italy. Bulletin of Insectology, 65, 51-61.

Zappala, L., Biondi, A., Alma, A., Al-Jboory, I. J., Arno, J., Bayram, A. and Shaltiel-Harpaz, L. (2013). Natural enemies of the South American moth, Tuta absoluta, in Europe, North Africa and Middle East, and their potential use in pest control strategies. Journal of Pest Science, 86(4), 635-647. 